\title{
Organic and inorganic geochemistry of low temperature gas discharges at the Baia di Levante beach, Vulcano Island, Italy
}

\author{
B. Capaccioni ${ }^{\mathrm{a}, *}$, F. Tassi ${ }^{\mathrm{b}}$, O. Vaselli ${ }^{\mathrm{b}}$ \\ ${ }^{a}$ Institute of Volcanology and Geochemistry, University of Urbino, Loc. Crocicchia, Ex-Sogesta-61029 Urbino, Italy \\ ${ }^{\mathrm{b}}$ Department of Earth Sciences, University of Florence, Via G. La Pira, 4-50121 Florence, Italy
}

\begin{abstract}
Discharge from subaereal and submarine gas vents of the Baia di Levante beach gases from the Vulcano Island were sampled for major and trace gas components in May and November 1995.

Chemical compositions and equilibrium calculations suggest three different groups of $\mathrm{CO}_{2}$-rich gas emissions depending on their distance from the La Fossa crater: (1) gas vents close to the Faraglione area are characterised by high $\mathrm{H}_{2} \mathrm{~S}$ contents, high calculated equilibrium temperatures based on inorganic species and relatively high proportion of alkene compounds; (2) gas vents close to Vulcanello are characterised by low calculated equilibrium temperatures and low amounts of alkenes; and (3) Pontile sample has the highest equilibrium $\mathrm{CO}_{2}$ pressure (up to 68 bars) which may account for the observed absence of benzene. The relative large variability of $\mathrm{H}_{2} \mathrm{~S}$ in the Baia di Levante beach gas discharge may be attributed to either different interactions between iron sulphides and weakly acid waters or catalytic effect of elemental sulphur on the de-hydrogenation of cyclo-hexane. Thermodynamic calculations suggest that the main inorganic species and $\mathrm{CH}_{4}$ may have re-equilibrated at relatively shallow depth (10-200 m b.s.l. and 30-600 m b.s.l. for a lithostatic and hydrostatic pressure, respectively). The slow kinetics of reactions in the $\mathrm{C}_{n} \mathrm{H}_{2 n} / \mathrm{C}_{n} \mathrm{H}_{2 n+2}$ systems, with respect to that of $\mathrm{CH}_{4}-\mathrm{CO}-\mathrm{CO}_{2}$, may explain the observed propene/propane ratios, which can only be reached at reaction temperatures of $300-350^{\circ} \mathrm{C}$. This low speed of reactions can also explain the observed disequilibrium of C1-C4 alkanes. (C) 2001 Elsevier Science B.V. All rights reserved.
\end{abstract}

Keywords: Gas geochemistry; Organic gases; Fumarole discharge; Thermodynamics; Vulcano Island

\section{Introduction}

Vulcano is the southernmost of the seven volcanic islands of the Aeolian Archipelago (Sicily, southern Italy), that is referred to a typical volcanic subductionrelated arc (Barberi et al., 1974; Beccaluva et al., 1985). Its volcanic activity commenced in the Upper Pleistocene and may be divided into four cycles (Keller, 1980; Frazzetta et al., 1984). Its last eruptive

\footnotetext{
* Corresponding author. Tel.: +39-0722-304252; fax: +39-0722304245.

E-mail address: b.capaccioni@geo.uniurb.it (B. Capaccioni).
}

event took place during August 1888 to March 1890 within the La Fossa caldera, a 391-m-high cone (Mercalli and Silvestri, 1888; Silvestri and Mercalli, 1891). Since then, a fumarolic activity has persisted in both the north-western part of the crater rim and along the Baia di Levante beach.

Flow rate, chemical composition and temperature of the fumaroles at the crater display relatively large variations in time (Martini, 1989, 1993; Barberi et al., 1991; Italiano and Nuccio, 1992). In 1923, Sicardi (1940) recorded temperatures up to $600^{\circ} \mathrm{C}$, and then for a long period they remained $<250^{\circ} \mathrm{C}$ (Chiodini et al., 1992). In 1978, the fumarolic activity showed a 


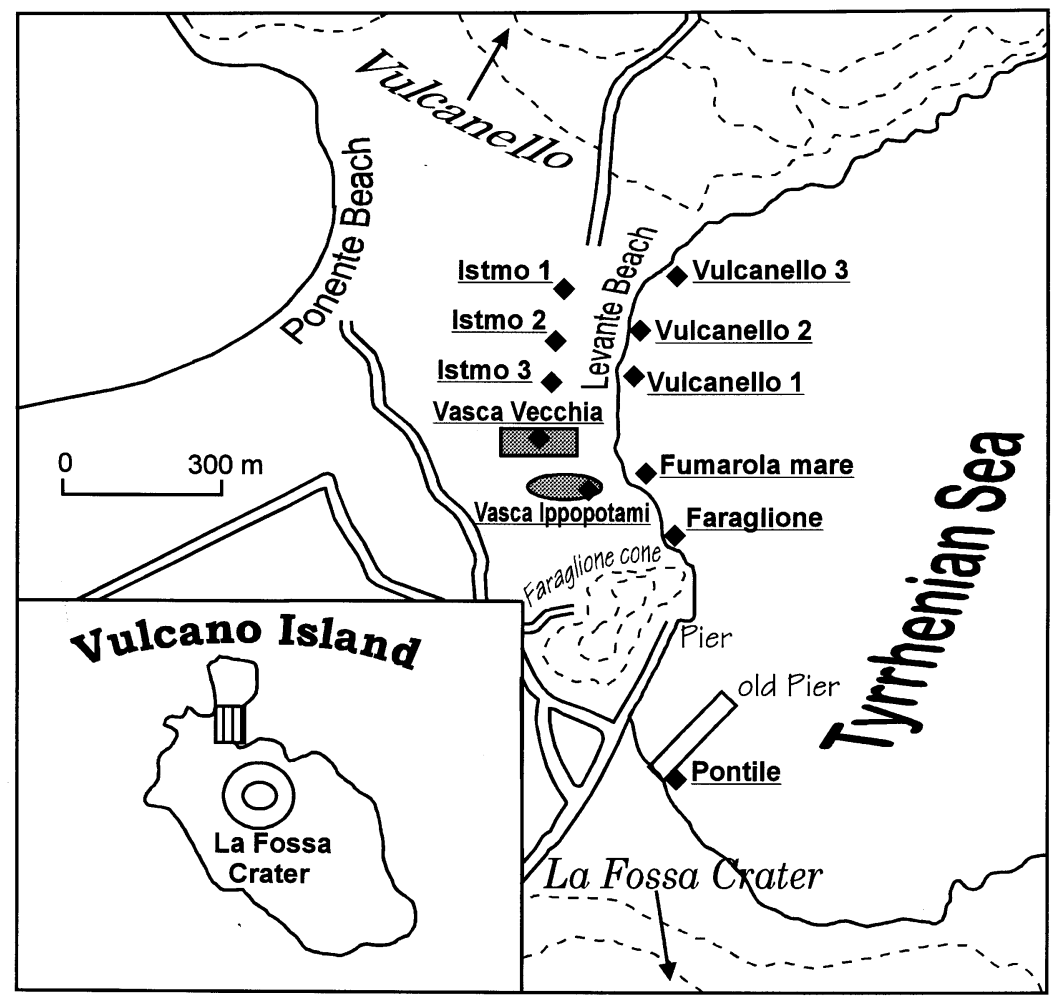

Fig. 1. Location of the gas sampling sites.

rapid variation (Martini, 1983), and since 1987 temperatures at the La Fossa crater increased reaching $650^{\circ} \mathrm{C}$ in 1991 (Chiodini et al., 1993; Martini, 1993). Presently, the crater fumarole temperatures are $<400^{\circ} \mathrm{C}$ (Chiodini et al., 1995).

The very first report dealing with the physics and chemistry of the Vulcano fluids dates back to the 19th century (Sainte-Claire Deville, 1856; Fouquè, 1865). Since then, gas emissions, thermal waters, soil gases and volcanic products of the La Fossa crater have been extensively studied (e.g. Martini and Tonani, 1970; Shinoara and Matsuo, 1986; Badalamenti et al., 1988; Baurbon et al., 1990; Panichi and Noto 1992; Minissale, 1992; Bolognesi and D'Amore, 1993; Martini, 1996). During the early '80s, the origin and the physical and chemical features of the Vulcano fluids have been a matter of debate and several models have been suggested. Martini et al. (1980) stressed the existence of a shallow aquifer between the magma chamber and the surface controlling both the thermal output and the chemical composition of the fumarole discharge. Carapezza et al. (1981) suggested the presence of a pressurised two-phase (liquid-vapour) saline reservoir, at the depth of about $2 \mathrm{~km}$, evolving along a boiling trend of a liquid with $10 \% \mathrm{NaCl}, 1.5-$ $2 \% \mathrm{CO}_{2}$ at $350^{\circ} \mathrm{C}$ ("pressure cooker" model). Cioni and D'Amore (1984) stated that the fluids feeding the fumarolic system of the La Fossa crater derived from the mixing of deep magmatic components and shallower components produced by evaporation of brines seeping into the fumarolic conduits from lateral aquifers ("dry" model).

However, much less attention has been paid to the Baia di Levante beach gas discharge since its relatively low temperature $\left(100^{\circ} \mathrm{C}\right)$ remained almost constant during the last century (Chiodini et al., 1991b). Accordingly, they have been interpreted as gas emissions from a hydrothermal aquifer associated with magmatic fluids feeding the crater fumaroles and modified by secondary low-temperature sub-surface processes (Martini et al., 1980; Cioni and D'Amore, 1984; Mazor et al., 1988; Chiodini et al., 1991a, 
Table 1

Chemical compositions of major gas species of the Baia di Levante beach (Vulcano Island, Aeolian Archipelago, southern Italy) gas discharges. $\mathrm{CO}_{2}, \mathrm{H}_{2} \mathrm{~S}, \mathrm{~N}_{2}, \mathrm{CH}_{4}$ are in $\%$ by vol. while $\mathrm{O}_{2}, \mathrm{Ar}, \mathrm{H}_{2}, \mathrm{He}$ and $\mathrm{CO}$ are in ppm

\begin{tabular}{|c|c|c|c|c|c|c|c|c|c|c|c|}
\hline & Code & $\mathrm{CO}_{2}$ & $\mathrm{H}_{2} \mathrm{~S}$ & $\mathrm{~N}_{2}$ & $\mathrm{CH}_{4}$ & $\mathrm{O}_{2}$ & $\mathrm{Ar}$ & $\mathrm{H}_{2}$ & $\mathrm{He}$ & $\mathrm{CO}$ & $\mathrm{T}$ \\
\hline \multicolumn{12}{|l|}{ May 1995} \\
\hline Pontile & Po & 98.08 & $<0.005$ & 1.88 & 0.004 & $<1$ & 268 & 3.3 & 0.2 & 0.07 & 20 \\
\hline Faraglione & $\mathrm{Fa}$ & 95.92 & 0.805 & 2.08 & 0.169 & $<1$ & 301 & 9900 & 2.9 & 0.16 & 20 \\
\hline Fumarola mare & FM & 96.68 & 2.158 & 0.62 & 0.076 & $<1$ & 54 & 4600 & 1.1 & 0.11 & 90 \\
\hline Vasca Ippopotami & VI & 96.89 & 2.467 & 0.69 & 0.201 & $<1$ & 12 & 479 & 0.7 & 0.2 & 42 \\
\hline Vasca Vecchia & VV & 96.76 & 2.239 & 0.63 & 0.084 & $<1$ & 38 & 2800 & 0.1 & 0.23 & 93 \\
\hline Istmo 1 & Is 1 & 98.17 & $<0.005$ & 1.65 & 0.151 & $<1$ & 254 & 3.5 & 6.5 & 0.04 & 60 \\
\hline Istmo 2 & Is 2 & 97.72 & 1.573 & 1.57 & 0.092 & $<1$ & 28 & 181 & 2.2 & 0.02 & 60 \\
\hline Istmo 3 & Is3 & 95.39 & 2.271 & 1.85 & 0.276 & $<1$ & 114 & 2000 & 6.1 & 0.21 & 60 \\
\hline Vulcanello 1 & Vu1 & 98.09 & 0.797 & 1.00 & 0.102 & $<1$ & 142 & 7.2 & 2.2 & $<0.01$ & 20 \\
\hline Vulcanello 2 & Vu2 & 97.78 & 1.024 & 1.03 & 0.071 & $<1$ & 139 & 774 & 2.1 & $<0.01$ & 20 \\
\hline Vulcanello 3 & Vu3 & 76.19 & $<0.005$ & 23.21 & 0.171 & $<1$ & 4300 & 10.8 & 93 & $<0.01$ & 20 \\
\hline \multicolumn{12}{|l|}{ November 1995} \\
\hline Pontile & Po & 96.89 & $<0.005$ & 3.11 & 0.003 & 7300 & 422 & 3.8 & 0.4 & 0.04 & 20 \\
\hline Faraglione & $\mathrm{Fa}$ & 97.39 & 0.373 & 2.10 & 0.133 & 1400 & 318 & 7300 & 1.1 & 0.06 & 20 \\
\hline Fumarola mare & FM & 97.65 & 1.512 & 0.77 & 0.055 & 2 & 76 & 6600 & 1 & 0.08 & 90 \\
\hline Vasca Ippopotami & VI & 97.26 & 1.863 & 0.66 & 0.224 & 5 & 30 & 554 & 0.6 & 0.15 & 42 \\
\hline Vasca Vecchia & VV & 96.97 & 2.344 & 0.57 & 0.097 & 2 & 19 & 3100 & 0.5 & 0.18 & 93 \\
\hline Istmo 1 & Is 1 & 98.36 & 0.074 & 1.40 & 0.166 & 197 & 160 & 2.1 & 7.7 & 0.03 & 60 \\
\hline Istmo 2 & Is 2 & 97.26 & 2.142 & 0.52 & 0.087 & 3 & 24 & 194 & 3.9 & 0.01 & 60 \\
\hline Istmo 3 & Is 3 & 96.92 & 2.195 & 0.72 & 0.155 & $<1$ & 48 & 2200 & 4.5 & 0.12 & 60 \\
\hline Vulcanello 1 & Vu1 & 98.19 & 0.613 & 1.02 & 0.144 & 2200 & 450 & 5.6 & 3.1 & $<0.01$ & 20 \\
\hline Vulcanello 2 & $\mathrm{Vu} 2$ & 97.79 & 1.052 & 0.97 & 0.096 & 615 & 122 & 568 & 2.9 & $<0.01$ & 20 \\
\hline Vulcanello 3 & Vu3 & 84.59 & $<0.005$ & 15.21 & 0.171 & 18000 & 2300 & 5.4 & 69 & $<0.01$ & 20 \\
\hline
\end{tabular}

1995). In the present study, 11 subaereal and submarine gas vents between the old Vulcano pier and Vulcanello peninsula, along the Baia di Levante beach (Fig. 1), were collected for major, minor and trace gas analyses. For evaluation of temporal stability of the gas chemistry, sampling was made in both May and November 1995.

\section{Sampling and analysis}

The Baia di Levante beach gas discharges comprise subaerial bubbling gas pools (Vasca Ippopotami, VI, Vasca Vecchia, VV, Istmo 1, 2 and 3, Is1, 2, 3) and submarine gas emissions (Pontile, Po, Faraglione, Fa, Fumarola mare, FM, Vulcanello 1, 2 and 3, Vu1, 2, 3) emerging few meters from the beach at about $1 \mathrm{~m}$ depth (Fig. 1). They are mainly exposed close to the Faraglione tuff cone (Fumarola mare, FM, Vasca degli Ippopotami, VI, Vasca Vecchia, VV and Faraglione, Fa; hereafter named "Southern Isthmus") emerging from both the shoreline and the sea. However, about $100 \mathrm{~m}$ south of the Faraglione tuff cone, below the old Vulcano pier, we collected the Pontile (Po) gas which is the sample closest to the La Fossa crater. North of Faraglione (Fig. 1) two gas emitting lineaments emerge in both the Isthmus and in the sea towards Vulcanello (Is1, 2 and 3 and Vu1, 2 and 3) (hereafter named "Northern Isthmus"). These eleven samples were collected in May and in November 1995. FM and VI gases have the highest fluxes, while Po, Fa, Is1-3 and Vu1-3 display gentle bubbling.

Gas collection was made through an inverted plastic funnel connected to a gas-reservoir with two stopcocks for the analyses of reactive gases and $\mathrm{N}_{2}$ determination, or to a pre-evacuated $100-\mathrm{ml}$ oneway tubes containing $50 \mathrm{ml} 4 \mathrm{~N} \mathrm{NaOH}$ solution, for analysis of inert, low-abundance gases (Giggenbach, 1975a). Major and trace gases $\left(\mathrm{CO}_{2}, \mathrm{H}_{2} \mathrm{~S}, \mathrm{~N}_{2}, \mathrm{O}_{2}, \mathrm{Ar}\right.$, $\mathrm{CH}_{4}, \mathrm{H}_{2}$, He and $\mathrm{CO}$ ) were analysed with a Shimadzu $15 \mathrm{~A}$ and Shimadzu 15A gas-chromatographs with 


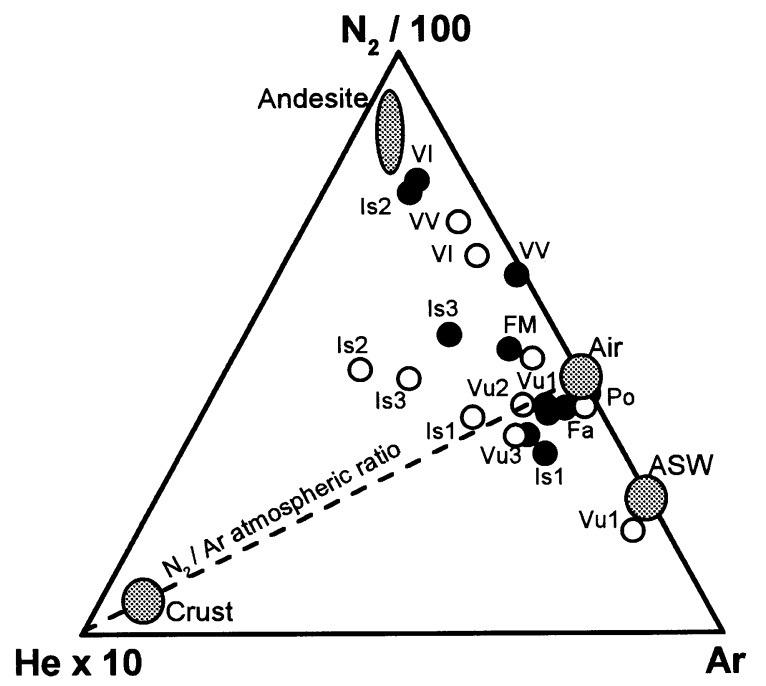

Fig. 2. $\mathrm{N}_{2} / 100-\mathrm{Ar}-\mathrm{He} * 10$ ternary diagram (after Giggenbach et al., 1993) for the Baia di Levante beach gas vents. Closed circles, May 1995; open circles, November 1995.

thermal conductivity and flame ionisation (CO) detectors, respectively. Light hydrocarbons were analysed with a gas-chromatograph according to the methods of Mangani et al. (1991) and Capaccioni et al. (1993).

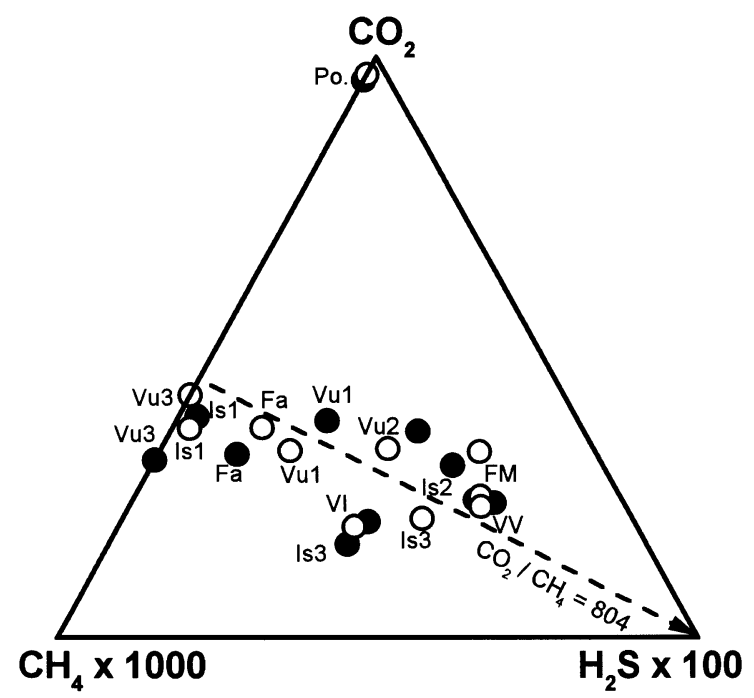

Fig. 3. $\mathrm{CO}_{2}-\mathrm{CH}_{4} \times 1000-\mathrm{H}_{2} \mathrm{~S} \times 100$ ternary diagram. Dashed line represents $\mathrm{CO}_{2} / \mathrm{CH}_{4}$ ratio equal to 804. Closed circles, May 1995; open circles, November 1995.

\section{Results}

Analytical data for major, minor and trace gas compounds for May and November 1995 are reported in Table 1. Gas samples are characterised by $\mathrm{CO}_{2}$ contents of $>76 \%$ by volume. With the exception of sample Vu3 which increases its content up to $84.9 \%$ in November 1995, significant $\mathrm{CO}_{2}$ variations were not found between the two field sessions. Similar behaviour has been recorded for $\mathrm{N}_{2}$ contents which ranges between 0.5 and $3.1 \%$. Only Vu3 has $\mathrm{N}_{2}$ values changed from 23.2 to $15.2 \%$ in May and November, respectively, which could be related to some air contamination during sampling since Ar values are $4279 \mathrm{ppm}$ in May and $2262 \mathrm{ppm}$ in November.

$\mathrm{N}_{2} /$ Ar ratios range between $83\left(\mathrm{~N}_{2} / \mathrm{Ar}\right.$ ratio in the air) and $38\left(\mathrm{~N}_{2} / \mathrm{Ar}\right.$ ratio in air saturated water at ambient temperature, ASW) (Fig. 2) for Vu1, 2 and 3, Is1, Po and Fa samples. The FM, VV, VI, Is 2 and 3 have $\mathrm{N}_{2} /$ Ar ratios $>100$, the highest value being found at VI (575 in May 1995), suggesting a large contribution of non-atmospheric $\mathrm{N}_{2}$.

A significant variability of hydrogen sulphide contents was observed ranging from $<0.8 \%$ ( $\mathrm{Fa}$, $\mathrm{Vu} 1$, Is1) to $2.5 \%$ (VI); $\mathrm{H}_{2} \mathrm{~S}$ contents of $\mathrm{Po}$ and $\mathrm{Vu} 3$ are below detection limit $(0.005 \%)$ but show almost constant $\mathrm{CO}_{2} / \mathrm{CH}_{4}$ value $\left(0.8 \times 10^{3}\right)$ (Fig. 3). Methane contents remained $<0.3 \%$ in sample from both the field sessions.

Apart from Vu3 which has He contents of 69 and 93 ppm (May and November 1995, respectively), relatively low values of $\mathrm{He}$ and $\mathrm{CO}(0.1-7.7$ and $<0.01-0.23 \mathrm{ppm}$, respectively) are found for all the Baia di Levante beach samples. A large variability was observed for $\mathrm{H}_{2}$ abundances, ranging from $<12 \mathrm{ppm}$ (Po, Is1, Vu1 and 3) up to $10,000 \mathrm{ppm}$ (Fa, May '95). The highest $\mathrm{H}_{2}$ values are observed at the gas emissions close the Faraglione tuff-cone, i.e. Is2 and 3, FM, Fa, VV and VI (Fig. 1 and Table 1).

Light hydrocarbon analysis (with exception of $\mathrm{CH}_{4}$ ) of the gas discharges for the two sampling sessions are reported in Table 2. Ten species of light hydrocarbons belonging to the alkane, alkene and aromatic groups were detected. Alkanes are mainly normal-alkanes, minor abundances of iso-alkanes and traces of cycloalkanes are also observed. iso-Butene and propene were commonly found. Benzene is the only aromatic hydrocarbon detected. After methane, ethane is the 
Table 2

Light hydrocarbon concentrations for the Baia di Levante beach gas discharges. All values are in ppb

\begin{tabular}{|c|c|c|c|c|c|c|c|c|c|c|c|}
\hline & Code & Ethane & Propene & Propane & $i$-Butane & $i$-Butene & $n$-Butane & $i$-Pentane & $n$-Pentane & Benzene & c-Esane \\
\hline \multicolumn{12}{|l|}{ May 1995} \\
\hline Pontile & Po & & & & & & & & & & \\
\hline Faraglione & $\mathrm{Fa}$ & & & 8 & 20 & & & & & 45 & \\
\hline Fumarola mare & FM & & 3 & & 11 & & & & & 143 & \\
\hline Vasca Ippopotami & VI & & & 95 & 3 & 5 & 40 & & & 215 & \\
\hline Vasca Vecchia & VV & & 3 & & & 27 & 36 & & & 379 & \\
\hline Istmo 1 & Is 1 & 3117 & 15 & 252 & 25 & 30 & 59 & & & 24 & \\
\hline Istmo 2 & Is 2 & 2059 & 8 & 139 & 18 & 17 & 31 & & & 440 & \\
\hline Istmo 3 & Is 3 & 5215 & 351 & 4400 & 269 & 271 & 450 & & & 2039 & \\
\hline Vulcanello 1 & Vu1 & 2018 & 7 & 163 & 21 & 20 & 42 & & & 216 & \\
\hline Vulcanello 2 & $\mathrm{Vu} 2$ & 1513 & 29 & 219 & 1 & 13 & 38 & & & 384 & \\
\hline Vulcanello 3 & Vu3 & 5096 & 33 & 298 & 102 & 129 & 50 & & & 20 & \\
\hline \multicolumn{12}{|l|}{ November 1995} \\
\hline Pontile & Po & 131 & & 37 & 6 & 28 & 12 & 9 & 3 & & 16 \\
\hline Faraglione & $\mathrm{Fa}$ & & & 13 & 4 & 25 & & & & 67 & \\
\hline Fumarola mare & FM & & 2 & 2 & & 3 & & & & 143 & \\
\hline Vasca Ippopotami & VI & & 122 & & & 112 & 11 & & & 410 & 611 \\
\hline Vasca Vecchia & VV & & & & & & & & & & \\
\hline Istmo 1 & Is 1 & 1949 & & 384 & 42 & 17 & 75 & 22 & 22 & 34 & 11 \\
\hline Istmo 2 & Is 2 & 1025 & & 201 & 21 & 31 & 40 & 12 & 13 & 1234 & 11 \\
\hline Istmo 3 & Is 3 & 1419 & & 269 & 55 & 53 & 53 & 18 & 18 & 1661 & 18 \\
\hline Vulcanello 1 & Vu1 & 919 & & 182 & 20 & 11 & 37 & 11 & 9 & 31 & 2 \\
\hline Vulcanello 2 & $\mathrm{Vu} 2$ & 1618 & & 308 & 36 & 36 & 63 & 20 & 29 & 700 & 5 \\
\hline Vulcanello 3 & Vu3 & 10985 & & 1202 & 231 & 62 & 200 & 139 & 46 & 123 & 15 \\
\hline
\end{tabular}

most abundant hydrocarbon, its content ranging from 131 (Po, Nov '95) to 10,985 ppb (Vu3, Nov '95) although it was below detection limit in the Fa, FM, VV and VI gas samples ( $<100 \mathrm{ppb}$ ). Propane contents are generally one order of magnitude less than that of ethane except for Is3 in May '95 where propane content was $4400 \mathrm{ppb}$. Abundances of few tens of $\mathrm{ppb}$ are recorded for other alkanes and alkenes. Benzene, generally related to medium-high temperature hydrothermal system (Capaccioni et al., 1995), is $>1500 \mathrm{ppb}$ in Is3 sample while it ranges between 20 (Vu3, May '95) to $1200 \mathrm{ppb}$ (Vu2, Nov '95) for the remaining samples.

\section{Discussion}

\subsection{Physical parameters at the re-equilibration zone}

Equilibration temperatures were calculated on the basis of the following equilibrium among different carbon species (Bertrami et al., 1985):

$\mathrm{CH}_{4}+3 \mathrm{CO}_{2}=4 \mathrm{CO}+2 \mathrm{H}_{2} \mathrm{O}$

temperature and the equilibrium constant are related according to:

$t\left({ }^{\circ} \mathrm{C}\right)=\frac{13605.63}{8.0651-\log \frac{X_{\mathrm{CO}}^{4}}{X_{\mathrm{CO}_{2}}^{3} X_{\mathrm{CH}_{4}}}}-273.15$

In presence of pure liquid water, the $P_{\mathrm{H}_{2} \mathrm{O}}$ is given by:

$\log P_{\mathrm{H}_{2} \mathrm{O}}=5.51-\frac{2048}{T(\mathrm{~K})}$

$P_{\mathrm{CO}_{2}}$ can be calculated with the following equilibrium reaction:

$\mathrm{CO}_{2}+\mathrm{H}_{2}=\mathrm{CO}+\mathrm{H}_{2} \mathrm{O}$

by combining $T=f\left(K_{\mathrm{eq}}\right)$ with Eq. (3):

$\log P_{\mathrm{CO}_{2}}=3.573-\frac{46}{T(\mathrm{~K})}-\log \frac{X_{\mathrm{H}_{2}}}{X_{\mathrm{CO}}}$ 
Table 3

Equilibrium temperatures, partial and total pressures calculated for some of the gas species from the Baia di Levante beach

\begin{tabular}{|c|c|c|c|c|c|c|c|}
\hline & Code & $T\left({ }^{\circ} \mathrm{C}\right)$ & $P_{\mathrm{CO}_{2}}$ & $P_{\mathrm{H}_{2} \mathrm{O}}$ & $P_{\mathrm{H}_{2} \mathrm{~S}}$ & $P_{\mathrm{H}_{2}}$ & $P \mathrm{t}$ \\
\hline \multicolumn{8}{|l|}{ May 1995} \\
\hline Pontile & Po & 149 & 61.09 & 4.51 & - & 0.21 & 67.64 \\
\hline Faraglione & $\mathrm{Fa}$ & 146 & 0.05 & 4.26 & $<1$ & 0.50 & 4.31 \\
\hline Fumarola mare & FM & 150 & 1.22 & 4.73 & 31 & 0.60 & 5.99 \\
\hline Vasca Ippopotami & VI & 159 & 0.24 & 5.87 & 6 & 0.70 & 6.12 \\
\hline Vasca Vecchia & VV & 142 & 1.22 & 3.82 & 2 & 0.32 & 3.89 \\
\hline Istmo 1 & Is 1 & 150 & 0.31 & 4.67 & 7 & 0.64 & 4.99 \\
\hline Istmo 2 & Is2 & 107 & 0.31 & 1.32 & 5 & 0.18 & 1.64 \\
\hline Istmo 3 & Is 3 & 118 & 33.07 & 1.86 & - & $<0.01$ & 35.54 \\
\hline Vulcanello 1 & Vu1 & 94 & 3.87 & 0.86 & 31 & 0.01 & 4.80 \\
\hline Vulcanello 2 & Vu2 & 96 & 0.04 & 0.91 & $<1$ & 0.03 & 0.95 \\
\hline Vulcanello 3 & Vu3 & 95 & 2.60 & 0.89 & - & 0.04 & 4.30 \\
\hline \multicolumn{8}{|l|}{ November 1995} \\
\hline Pontile & Po & 136 & 27.43 & 3.17 & - & 0.11 & 31.48 \\
\hline Faraglione & $\mathrm{Fa}$ & 125 & 0.02 & 2.33 & $<1$ & 0.15 & 2.35 \\
\hline Fumarola mare & FM & 142 & 0.76 & 3.83 & 14 & 0.43 & 4.60 \\
\hline Vasca Ippopotami & VI & 153 & 0.17 & 5.02 & 4 & 0.53 & 5.19 \\
\hline Vasca Vecchia & VV & 137 & 0.03 & 3.25 & $<1$ & 0.20 & 3.28 \\
\hline Istmo 1 & Is 1 & 139 & 0.15 & 3.52 & 4 & 0.35 & 3.68 \\
\hline Istmo 2 & Is 2 & 98 & 0.17 & 0.98 & 4 & 0.04 & 1.16 \\
\hline Istmo 3 & Is 3 & 108 & 33.58 & 1.38 & 2.5 & 0.07 & 35.52 \\
\hline Vulcanello 1 & Vu1 & 93 & 5.04 & 0.81 & 31 & 0.03 & 5.94 \\
\hline Vulcanello 2 & $\mathrm{Vu} 2$ & 94 & 0.05 & 0.87 & 1 & 0.03 & 0.92 \\
\hline Vulcanello 3 & Vu3 & 95 & 5.16 & 0.90 & - & 0.03 & 7.00 \\
\hline
\end{tabular}

As stated by Bertrami et al. (1985) and Chiodini and Cioni (1989), the Eqs. (2) and (5) do not take into account the different solubility of the gaseous species into water, even if this can be overcome when vapour fraction at the equilibration zone exceeds $5 \%$ by weight. Chiodini et al. (1991a) report a good agreement between the calculated parameters and data from a geothermal well in the area of Vulcano beach.

The calculated equilibrium temperatures, partial and total pressures for some of the analysed gas components are shown in Table 3. Samples collected close to the Faraglione area have the highest temperatures, ranging between 125 and $159^{\circ} \mathrm{C}(\mathrm{Fa}, \mathrm{Po}, \mathrm{VI}$, FM, Is3 and VV sample). Samples collected along the Isthmus and close to the Vulcanello area show lower equilibration temperatures ranging from 93 to $118^{\circ} \mathrm{C}$. The calculated total pressure $\left(P_{\mathrm{t}}\right)$ are ranging from $<1$ to 68 bars (Po, May 1995). High total pressures are resulted from high $P_{\mathrm{CO}_{2}}$, especially at Pontile (Po) and Istmo 1 (Is3). The calculated temperatures generally decreased from May to
November. The calculated total pressures for the samples from the Faraglione area significantly decreased because of the lowering of both gas and vapour pressures. On the contrary, in spite of decreasing temperatures, in samples collected near Vulcanello area, $\mathrm{CO}_{2}$ partial pressures show a minor increase.

\subsection{Formation of hydrogen sulphide by alkaline hydrolysis of iron sulphide}

Among sulphur species, $\mathrm{H}_{2} \mathrm{~S}$ has been considered as low temperature equilibrium product at hydrothermal re-equilibration zone. Giggenbach (1975b) stressed the importance of $\mathrm{H}_{2} \mathrm{~S} / \mathrm{SO}_{2}$ buffer system in a gaseous phase, Cellini Legittimo and Martini (1989) suggested a possible source for $\mathrm{H}_{2} \mathrm{~S}$ by the alkaline hydrolysis of metal sulphides promoted by weakly acid waters. Occurrence and interactions of the weakly acid waters in the edifice of active volcanoes are common. Hydrothermal alteration of rocks by hot and acid waters is indicated by the presence of amorphous silica, 


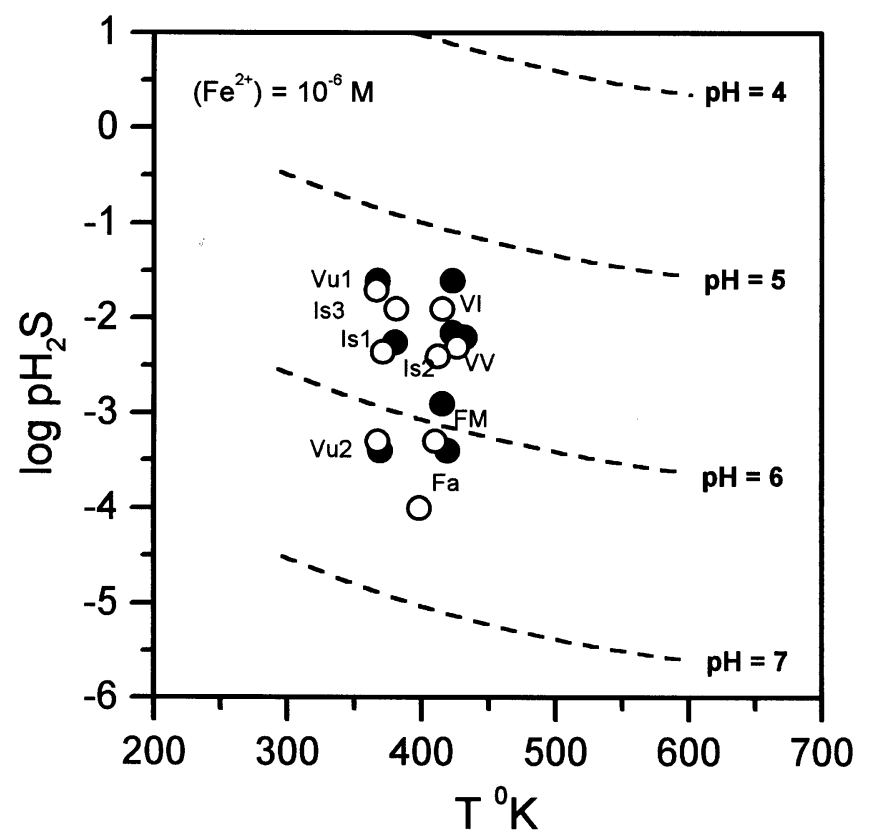

Fig. 4. Calculated $P_{\mathrm{H}_{2} \mathrm{~S}}$-equilibrium $T(\mathrm{~K})$ binary plot for the analysed samples. Dashed lines represent the expected $P_{\mathrm{H}_{2} \mathrm{~S}}$ at different $\mathrm{pH}$ and $T$ (K) for the reaction (6) (see text). Closed circles, May 1995; open circles, November 1995.

hallophane and kaolinite and the almost complete removal of aluminium and iron. The present water wells at the base of active La Fossa cone have $\mathrm{pH}$ values ranging from 5.5 to 7.5 with large amounts of sulphate and chloride although not heavy metals (Martini, 1980; Martini et al., 1981). The present compositions of high temperature emissions at the crater rim are characterised by high contents of acid species such as $\mathrm{SO}_{2}, \mathrm{HCl}$ and $\mathrm{HF}$ which, when added to lateral or surficial aquifers, might cause serious acidification (Martini et al., 1986, 1991; Martini, 1996). Moreover, iron sulphides have been recognised as coatings or grains or granular dispersions on the hydrothermally alterated volcanics. The sulphides are marcasite and/or pyrite, depending on the $\mathrm{pH}$ and temperature of the reacting water solutions (Murowchick and Barnes, 1986). Marcasite and pyrrhotite have been found in Vulcano Island (Capaccioni, unpublished data). Starting from the hypothesis that dispersed pyrrhotite mineralisation occurs along gas pathways to the surface, temperatures and $\mathrm{pH}$ conditions needed to produce the observed $P_{\mathrm{H}_{2} \mathrm{~S}}$ in the Vulcano beach gas emissions can be calculated with thermodynamic data (Barin and Knake, 1973).
Assuming equilibrium behaviour and iron (II) concentration in water close to saturation $\left(10^{-6} \mathrm{M}\right)$, the reaction:

$\mathrm{FeS}+2 \mathrm{H}^{+}=\mathrm{Fe}^{2+}+\mathrm{H}_{2} \mathrm{~S}$

is taken to control the relationships between $P_{\mathrm{H}_{2} \mathrm{~S}}$ and $\mathrm{pH}$ values are given in Fig. 4.

If we consider the calculated $P_{\mathrm{H}_{2} \mathrm{~S}}$ and measured $\mathrm{pH}$ values of thermal water (ranging from 5.5 to 7.5 ) from in 25 wells all around the harbour area (Martini et al., 1980), a significant overlapping can be observed. It may be concluded that the actual $P_{\mathrm{H}_{2} \mathrm{~S}}$ can be, at least partially, derived from acid water/sulphide interactions. Variable degree of interaction could be responsible of the wide observed variability of $\mathrm{H}_{2} \mathrm{~S}$ at constant $\mathrm{CO}_{2} / \mathrm{CH}_{4}$ ratios (Fig. 3). Such interactions may be confined to a certain depth, probably where deep rising fluids, similar to those emitted at the crater rim, reach and mix with the local aquifers.

\subsection{Degradation of hydrocarbon compounds}

With the exception of methane, gas samples collected along the Baia di Levante beach contain a 


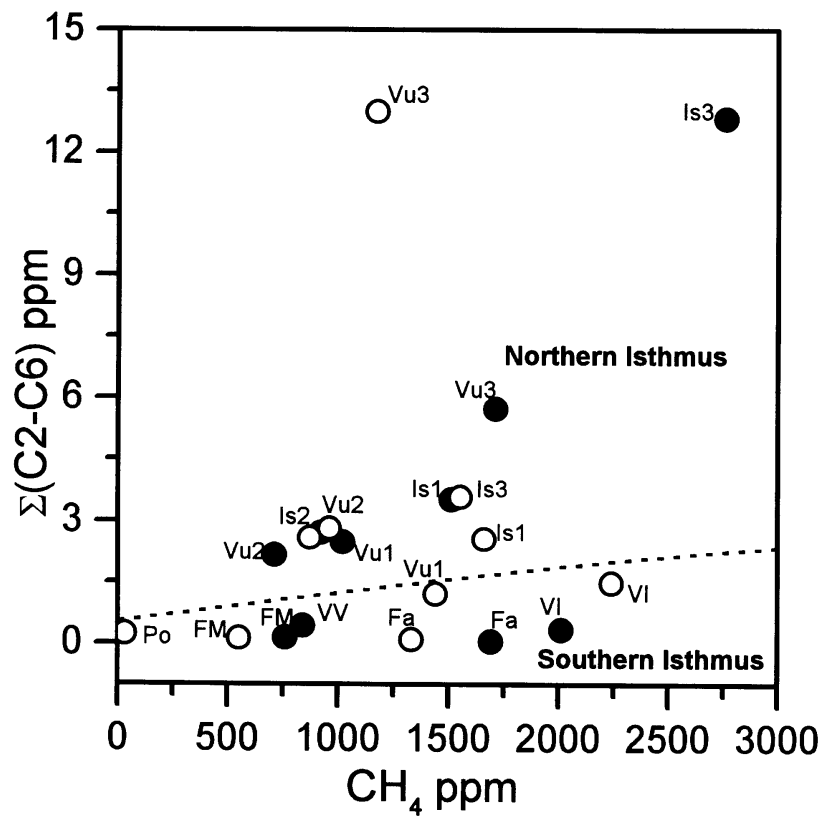

Fig. 5. $\mathrm{CH}_{4}-\sum\left(\mathrm{C}_{2}-\mathrm{C}_{6}\right)$ binary diagram for the Baia di Levante gas vents. Closed circles, May 1995; open circles, November 1995 .

small amount of hydrocarbons (Table 2). The total content of hydrocarbons, heavier than methane, range from $73 \mathrm{ppb}(\mathrm{Fa}$, May '95) to $13,000 \mathrm{ppb}$ (Vu3, Nov '95). No correlation between methane and the total amount of heavier hydrocarbons is

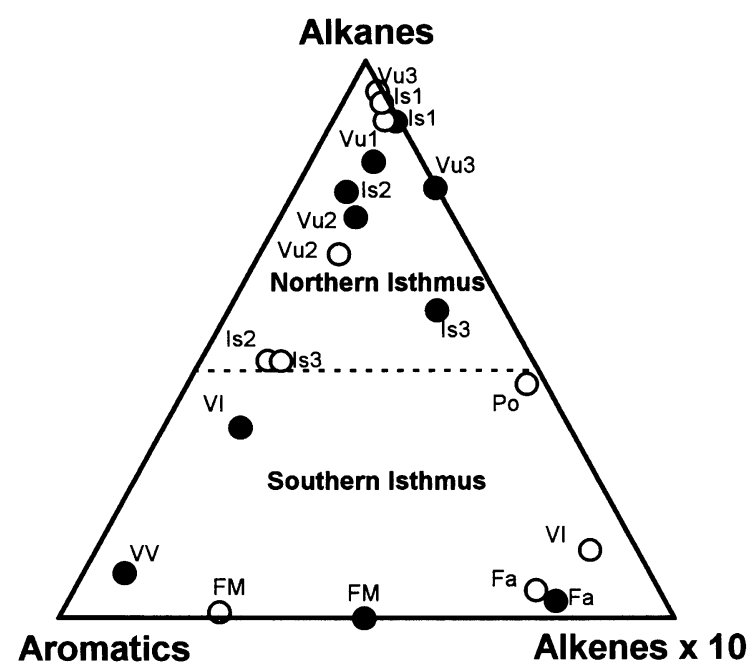

Fig. 6. Alkanes-Alkenes $\times 10$-Aromatics ternary diagram for the Baia di Levante beach gas vents. Closed circles, May 1995; open circles, November 1995. observed (Fig. 5). Moreover, samples collected in the Northern Isthmus (Vu1-3 and Is1-3 samples) show higher (one to two orders of magnitude) contents of heavier hydrocarbons than these from the southern part (VV, Fa, Po, FM and VI samples; Fig. 5).

The relative contents of hydrocarbon groups are plotted in the alkane-alkene-aromatic triangular diagram (Fig. 6). Samples collected along the Isthmus and close to Vulcanello area (Northern Isthmus) distribute from the alkanes corner ( Vu3, $\mathrm{Vu} 1$ and Is1 samples) to the middle area of the diagram (Is3, Vu2 and Is2 samples), while samples collected close to the remnant Faraglione cone structure (Fa, VI, FM and VV samples, Southern Isthmus) that are relatively enriched in benzene, iso-butene and propene, are plotted near alkene and benzene corners.

According to previous works (Capaccioni et al., 1993, 1995), alkane-rich gases are typical for very low temperature or even cold emissions, in which organic compounds derive directly from degrading organic matter at very reduced conditions. These hydrocarbons can reasonably be assumed to be derived by organic hydrolysis of fats and oils, 


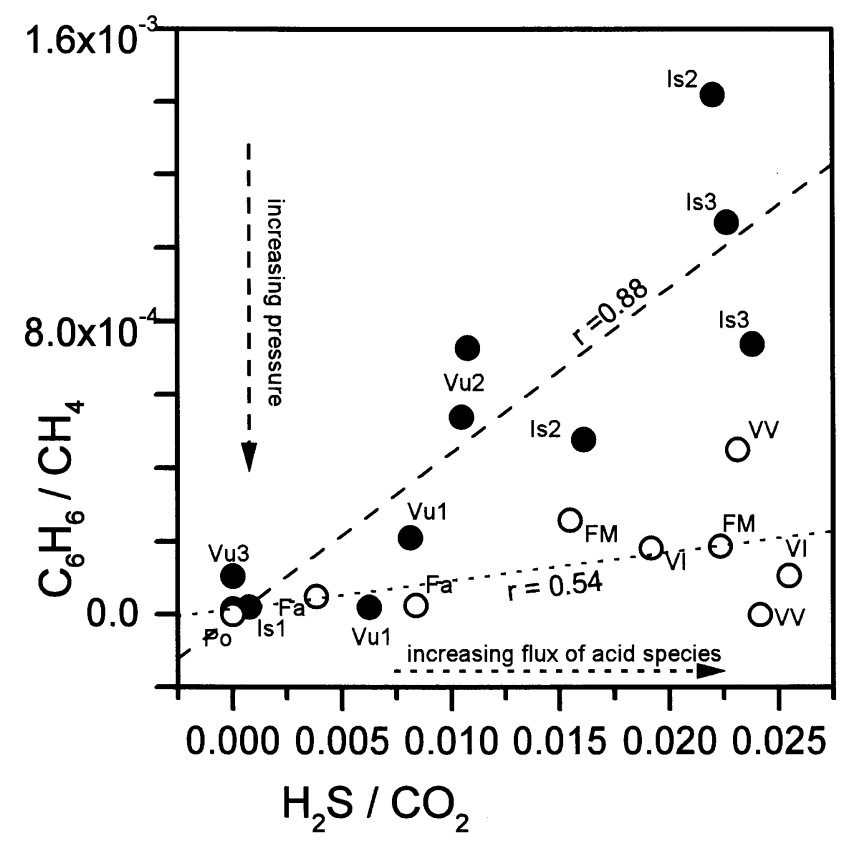

Fig. 7. $\mathrm{H}_{2} \mathrm{~S} / \mathrm{CO}_{2}-\mathrm{C}_{6} \mathrm{H}_{6} / \mathrm{CH}_{4}$ binary diagram for the Baia di Levante beach gases. Dashed lines represent the correlation lines for the two gas sampling sessions: May 1995 (closed circles) and November 1995 (open circles), respectively.

promoted by heating and/or by catalysis followed by decomposition of organic acids (Hedberg, 1964; Johns and Shimoyama, 1972).

Degradation effects are probably limited to cracking of long chain molecules to produce lighter alkanes other than saturated isomers (mainly iso-butane and minor iso-pentane). Increasing contents of benzene may indicate high degradation temperatures as well as the presence of suitable catalysts along the flowpath. Such conditions are able to promote de-hydrogenation of saturated hydrocarbons followed by the re-building of new molecules ("reforming reactions", Capaccioni et al., 1995), according to the following reactions:

$$
\begin{aligned}
& \mathrm{C}_{6} \mathrm{H}_{14} \rightarrow \mathrm{C}_{6} \mathrm{H}_{12}+\mathrm{H}_{2} \\
& \mathrm{C}_{6} \mathrm{H}_{12} \rightarrow \mathrm{C}_{6} \mathrm{H}_{6}+3 \mathrm{H}_{2} \\
& \mathrm{C}_{6} \mathrm{H}_{12}+3 \mathrm{~S} \rightarrow \mathrm{C}_{6} \mathrm{H}_{6}+3 \mathrm{H}_{2} \mathrm{~S}
\end{aligned}
$$

Whatever the reaction, production of cyclo-hexane and benzene, together with secondary hydrogen and hydrogen sulphide, reactions (7) and (8) increase number of moles, therefore production is not favoured under high pressure conditions. Acid water saturated zones, composed of smectites and or kaolinite, are very suitable catalysts for reactions (7) and (8). Reaction (8) whose main product is benzene, is favoured when elemental sulphur acts as a catalyst. As reported above, samples located close to the Faraglione cone (FM, VI, Fa and VV samples, or "Southern Isthmus") can be distinguished from the others ("Northern Isthmus") on the basis of both the temporal variations recorded between May and November 1995 and the calculated equilibrium temperatures. In Fig. 7, $\mathrm{H}_{2} \mathrm{~S} / \mathrm{CO}_{2}$ and $\mathrm{C}_{6} \mathrm{H}_{6} / \mathrm{CH}_{4}$ ratios are plotted for all the analysed samples. Both groups display general positive correlations, whereas samples from the Southern Isthmus show a lower correlation coefficient $(0.54)$ than those from the Northern Isthmus (0.88).

As previously suggested (Capaccioni et al., 1995), rapid gas upflows prevent interactions with minerals and water solutions and increasing reaction temperatures can promote following cracking 


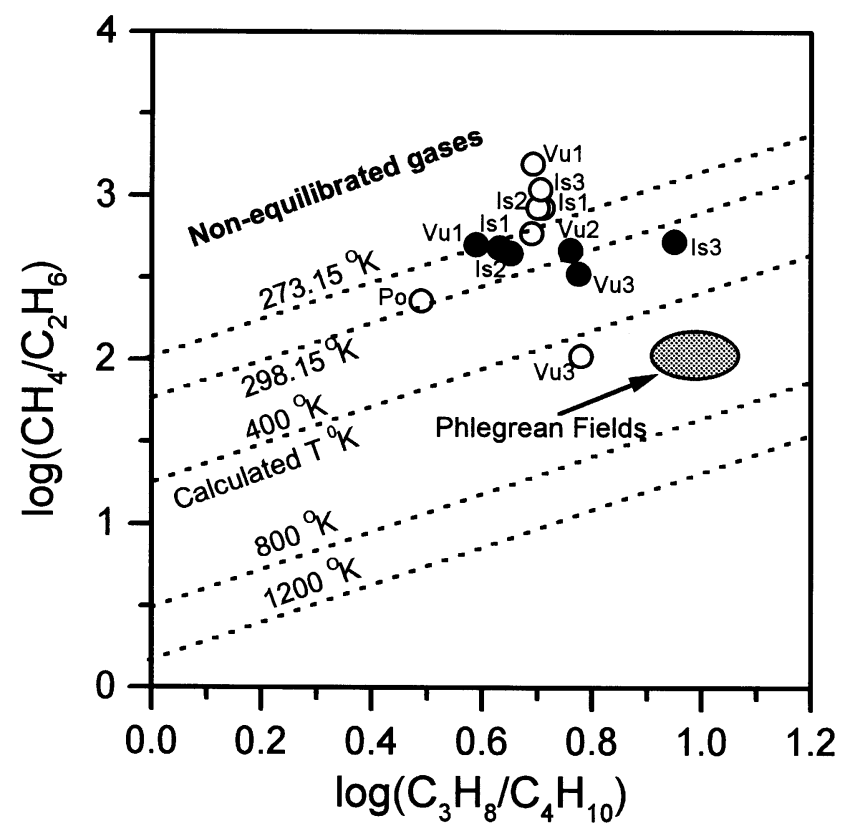

Fig. 8. $\log \left(\mathrm{C}_{3} \mathrm{H}_{8} / \mathrm{C}_{4} \mathrm{H}_{10}\right)$ vs. $\log \left(\mathrm{CH}_{4} / \mathrm{C}_{2} \mathrm{H}_{6}\right)$ binary diagram for the Baia di Levante beach gas vents. Phlegrean Fields: Capaccioni, unpublished data. Closed circles, May 1995; open circles, November 1995.

reactions:

$$
\begin{aligned}
& \mathrm{CH}_{3}-\left(\mathrm{CH}_{2}\right)_{8}-\mathrm{CH}_{3} \rightarrow \mathrm{CH}_{2}-\left(\mathrm{CH}_{2}\right)_{2}-\mathrm{CH}_{2}+\mathrm{H} \\
& \text { (n-decane) } \\
& +\mathrm{CH}_{2}-\left(\mathrm{CH}_{2}\right)_{3}-\mathrm{CH}_{2}+\mathrm{CH}_{3}
\end{aligned}
$$

where $\mathrm{CH}_{2}\left(\mathrm{CH}_{2}\right)_{2}-\mathrm{CH}_{2}$ represents highly reactive free radicals, which rapidly transform by displacing a hydrogen ("\ح") as follows:

$$
\begin{aligned}
& \mathrm{CH}_{2}-\left(\mathrm{CH}_{2}\right)_{2}-\mathrm{CH}_{2}+\mathrm{CH}_{2}-\left(\mathrm{CH}_{2}\right)_{3}-\mathrm{CH}_{2}+\underbrace{\mathrm{C}}_{\text {(butene) }}+\mathrm{CH}_{3}+\mathrm{CH}_{2} \\
& =\mathrm{CH}_{2}=\underset{\text { (pentene) }}{\mathrm{CH}-\mathrm{CH}_{2}-\mathrm{CH}_{\text {(methane) }}^{\mathrm{CH}_{4}}} \\
& =\mathrm{CH}-\underset{\mathrm{CH}_{2}-\mathrm{CH}_{2}}{\mathrm{CH}_{3}}+\mathrm{HH}_{4}
\end{aligned}
$$

in which the main products are methane, butene and pentene.

The cold sample from the old pier (Po) plots isolated between the alkane and alkene corners (Fig. 6). Its composition could strongly be influenced by the high equilibration pressure (more than 60 bars; Table 3 ). These high pressure conditions may explain a partial or total condensation of relatively heavier hydrocarbon species with lower volatility such as benzene, hexane etc.

As stated above, cracking reactions occur with the breakage of $\mathrm{C}-\mathrm{C}$ bonds. Two simple cracking reactions can decompose butane and propane as follows:

$\mathrm{C}_{3} \mathrm{H}_{8}=\mathrm{C}_{2} \mathrm{H}_{4}+\mathrm{CH}_{4}$

and

$\mathrm{C}_{4} \mathrm{H}_{10}=\mathrm{C}_{2} \mathrm{H}_{4}+\mathrm{C}_{2} \mathrm{H}_{6}$

The relative amounts of the hydrocarbon species are expected to be easily quenched during cooling due to the very low kinetic at low temperature $\left(<300-350^{\circ} \mathrm{C}\right)$. Accordingly, in the case of equilibrium conditions, possible attained at higher temperature, equilibrium constants can be written as:

$\log K_{1}=\frac{f \mathrm{C}_{2} \mathrm{H}_{4} f \mathrm{CH}_{4}}{f \mathrm{C}_{3} \mathrm{H}_{8}}$ 
and

$\log K_{2}=\frac{f \mathrm{C}_{2} \mathrm{H}_{4} f \mathrm{C}_{2} \mathrm{H}_{6}}{f \mathrm{C}_{4} \mathrm{H}_{10}}$

The following equations are obtained with thermodynamic data (Barin and Knake, 1973) for these equilibrium constants:

$\log K_{1}=0.3723-4435.2 / T(\mathrm{~K})$

and

$\log K_{2}=0.5077-5023 / T(\mathrm{~K})$

then from Eq. (16):

$$
\begin{aligned}
\log f \mathrm{C}_{2} \mathrm{H}_{4}= & 0.3723-4435.2 / T(\mathrm{~K}) \\
& -\log f \mathrm{CH}_{4} / f \mathrm{C}_{3} \mathrm{H}_{8}
\end{aligned}
$$

and substituting $\log f \mathrm{C}_{2} \mathrm{H}_{4}$ into Eq. (17) will give:

$$
\begin{aligned}
& \log f \mathrm{CH}_{4} / \mathrm{C}_{2} \mathrm{H}_{6}-\log f \mathrm{C}_{3} \mathrm{H}_{8} / \mathrm{C}_{4} \mathrm{H}_{10} \\
& =-0.12+587.79 / T(\mathrm{~K})
\end{aligned}
$$

With Eq. (17), we can evaluate the ratios of the main normal-alkane compounds as a function of temperature.

The $\mathrm{C}_{3} \mathrm{H}_{8} / \mathrm{C}_{4} \mathrm{H}_{10}$ and $\mathrm{CH}_{4} / \mathrm{C}_{2} \mathrm{H}_{6}$ ratios for the Vulcano samples are plotted in Fig. 8 as a function of temperature. Samples from Baia di Levante beach plot far away from any reasonable equilibrium temperature, that is calculated with inorganic reactions (e.g. reaction (1)). This may suggest that the $C_{1} / C_{2}$ ratios are in excess what may be expected from equilibrium as calculated from inorganic species. According to Sugisaki and Nagamine (1995) this is typical of a not thermochemically controlled biogenic production of gas. Instead of this hypothesis we believe that the observed disequilibrium could be related to re-equilibration of methane in the system $\mathrm{CH}_{4} / \mathrm{CO} / \mathrm{CO}_{2}$ and the quenching of the system $\mathrm{CH}_{4} / \mathrm{C}_{n} \mathrm{H}_{2 n} / \mathrm{C}_{n} \mathrm{H}_{2 n+2}$ during cooling. This does not occur for every hydrothermal systems from active volcanoes. For example samples collected at the Phlegrean Fields, were plotted well clustered close to the calculated "inorganic" temperatures (Fig. 8).

\section{Concluding remarks}

On the basis of the chemical compositions and equilibrium calculations, the $\mathrm{CO}_{2}$-rich gas emissions from Vulcano beach can be divided into three different groups: (1) gases emitted close to the Faraglione area; (2) gases emitted along the inner portion of the Isthmus and close to the Vulcanello area; and (3) gases emitted close to old pier (Pontile) area. The first group (Southern Isthmus) is characterised by the highest inorganic equilibration temperatures, high amounts of hydrogen sulphide, which significantly decrease from May to November 1995, and high proportion of alkene compounds. The second group (Northern Isthmus) seems to be less affected by a deep inflow, having low equilibration temperatures, a significant correlation between hydrogen sulphide and benzene contents and a relatively low amounts of alkene compounds. The third group, represented only by the Po samples, shows high equilibration $\mathrm{CO}_{2}$-pressures, reaching 68 bars in May 1995. The calculated high pressure can, however, be based on the absence of benzene in May 1995. According to thermodynamic calculations, major inorganic species and methane may be reequilibrated at relatively shallow depths. The minimum values of the re-equilibration depths range from 10 to $200 \mathrm{~m}$ b.s.l., and from 30 to $600 \mathrm{~m}$ b.s.l., under lithostatic and hydrostatic condition, respectively. Kinetic effects could be responsible for the disequilibrium of $\mathrm{C}_{1}-\mathrm{C}_{4}$ alkanes, probably because of the anomalous enrichment of methane due to its re-equilibration with inorganic carbon compounds.

Re-equilibration temperatures decreased from May to November. Pressure decreases in the Faraglione area, while it appears significantly to have been influenced by local $\mathrm{CO}_{2}$ accumulations near the old pier. The observed large variability of hydrogen sulphide contents can be interpreted as the result of different interactions between iron sulphide and weakly acid waters, but it could also result from elemental sulphur catalysis for dehydrogenation of cyclo-hexane. Clays saturated with acid water can promote dehydrogenation of normal-alkanes and naftenes to produce iso-butene and benzene. The effect of acid water on $\mathrm{H}_{2} \mathrm{~S}$ and benzene formation might be the cause of the observed significant 
correlation between hydrogen sulphide and benzene contents (Tables 1 and 2).

The present combined inorganic and organic geochemical modelling calls for further investigations of the low temperature discharge on Vulcano. Of special importance is to examine the present results with additional isotopic data on the trace components of the discharge.

\section{Acknowledgements}

Many thanks are due to M. Martini (University of Florence) for partly supporting the sampling sessions at Vulcano Island and for his criticism on an earlier version of the manuscript. This paper has greatly benefited from the comments of $\mathrm{H}$. Shinohara, N. Oskarsson and Y. Kiyosu.

\section{References}

Badalamenti, B., Guerrieri, S., Hauser, S., Parello, F., Valenza, M., 1988. Soil $\mathrm{CO}_{2}$ output in the island of Vulcano during the period 1984-1988: surveillance of gas hazard and volcanic activity. Rend. Soc. It. Miner. Petrol. 43, 893-899.

Barberi, F., Innocenti, F., Ferrara, G., Keller, J., Villari, L., 1974. Evolution of Eolian arc volcanism (southern Thyrhenian Sea). Earth Planet. Sci. Lett. 21, 269-276.

Barberi, F., Neri, G., Valenza, M., Villari, L., 1991. 1987-1990 unrest at Vulcano. Acta Vulcanol. 1, 95-106.

Barin, I., Knake, O., 1973. Thermochemical Properties of Inorganic Substances. Springer, Berlin.

Baurbon, J.C., Allard, P., Toutain, J.P., 1990. Diffuse volcanic emissions of carbon dioxide from Vulcano Island, Italy. Nature 344, 51-53.

Beccaluva, L., Gabbianelli, G., Lucchini, R., Rossi, P.L., Savelli, C., 1985. Petrology and K/Ar ages of volcanics dredged from the Eolian seamount: implications for geodynamic evolution of the southern Thyrrenian basin. Earth Planet. Sci. Lett. 74, $187-$ 208.

Bertrami, R., Cioni, R., Corazza, E., D’Amore, F., Marini, L., 1985. Carbon monoxide in geothermal gases. Reservoir temperature calculations at Larderello (Italy). Geotherm. Resour. Council, Trans. 9, 299-303.

Bolognesi, L., D'Amore, F., 1993. Isotopic variation of the hydrothermal system on Vulcano Island, Italy. Geochim. Cosmochim. Acta 9, 2069-2082.

Capaccioni, B., Martini, M., Mangani, F., 1995. Light hydrocarbons in hydrothermal and magmatic fumaroles: hints of catalytic and thermal reactions. Bull. Volcanol. 56, 593-600.

Capaccioni, B., Martini, M., Mangani, F., Giannini, L., Nappi, G., Prati, F., 1993. Light hydrocarbons in gas-emissions from volcanic areas and geothermal fields. Geochem. J. 27 (7), 7-17.
Carapezza, M., Nuccio, P.M., Valenza, M., 1981. Genesis and evolution of the fumaroles of Vulcano (Aeolian Islands, Italy): a geochemical model. Bull. Volcanol. 44-3, 547-563.

Cellini Legittimo, P., Martini, M., 1989. The ecological significance of the coexistence of sulphur dioxide and hydrogen sulphide in volcanic fumaroles. Chem. Ecol. 4, 15-20.

Chiodini, G., Cioni, R., 1989. Gas geobarometry for hydrothermal systems and its application to some Italian geothermal areas. Appl. Geochem. 4, 465-472.

Chiodini, G., Cioni, R., Falsaperla, S., Montalto, A., Guidi, M., Marini, L., 1992. Geochemical and seismological investigations at Vulcano (Aeolian Islands) during 1978-1989. J. Geophys. Res. 97, $11025-11032$.

Chiodini, G., Cioni, R., Guidi, M., Marini, L., 1991a. Geochemical variations at Fossa Grande crater fumaroles (Vulcano Island, Italy) in summer 1988. Acta Vulcanol. 1, 179-192.

Chiodini, G., Cioni, R., Marini, L., 1993. Reactions governing the chemistry of crater fumaroles from Vulcano Island, Italy, and implications for volcanic surveillance. Appl. Geochem. 8, 357371.

Chiodini, G., Cioni, R., Marini, L., Panichi, C., 1995. Origin of the fumarolic fluids of Vulcano island, Italy and implications for volcanic surveillance. Bull. Volcanol. 57, 99-110.

Chiodini, G., Cioni, R., Raco, B., Taddeucci, G., 1991b. Gas geobarometry applied to evaluate phreatic explosion hazard at Vulcano Island (Sicily, Italy). Acta Vulcanol. 1, 193-197.

Cioni, R., D'Amore, F., 1984. A genetic model for the crater fumaroles of Vulcano island (Sicily, Italy). Geothermics 13 (4), 375384.

Fouqué, F., 1865. Sur le phenomenes eruptifs de l'Italie Meridionale. C. R. Soc. Geol. Fr., Paris LXI, 565-567.

Frazzetta, G., La Volpe, L., Sheridan, M.F., 1984. Evolution of the Fossa cone, Vulcano. J. Volcanol. Geotherm. Res. 17, 329-360.

Giggenbach, W.F., 1975a. A simple method for the collection and analysis of volcanic gas samples. Bull. Volcanol. 39, 132-145.

Giggenbach, W.F., 1975b. Variations in the carbon, sulphur and chlorine contents of volcanic gas discharges from White Island, New Zealand. Bull. Volcanol. 26, 15-27.

Giggenbach, W.F., Sano, Y., Wakita, H., 1993. Isotopic compositions of helium and $\mathrm{CO}_{2}$ and $\mathrm{CH}_{4}$ contents in gases produced along the New Zealand part of a convergent plate boundary. Geochim. Cosmochim. Acta. 57, 3427-3455.

Hedberg, H.D., 1964. Geological aspects of the origin of petroleum. Am. Assoc. Pet. Geol. Bull. 48, 1755-1803.

Italiano, F., Nuccio, P.M., 1992. Volcanic steam output directly measured in fumaroles: the observed variations at Vulcano Island, Italy, between 1983 and 1987. Bull. Volcanol. 54, 623-630.

Johns, W.D., Shimoyama, A., 1972. Clay minerals and petroleumforming reactions during burial and diagenesis. Am. Assoc. Pet. Geol. Bull. 56, 2160-2167.

Keller, J., 1980. The Island of Vulcano. In: Villari, L. (Ed.), The Aeolian Islands, an Active Volcanic Arc in the Mediterranean Sea. Soc. It. Miner. Petrol. Milano, Italy, pp. 29-74.

Mangani, F., Cappiello, A., Capaccioni, B., Martini, M., 1991. Sampling and analysis of light hydrocarbons in volcanic gases. Chromatographia 32, 441-444. 
Martini, M., 1980. Geochemical survey on the phreatic waters of Vulcano (Aeolian Islands, Italy). Bull. Volcanol. 43, 265-274.

Martini, M., 1983. Variations in surface manifestation at Vulcano (Aeolian Islands, Italy) as a possible evidence of deep processes. Bull. Volcanol. 46-1, 83-86.

Martini, M., 1989. The forecasting significance of chemical indicators in areas of quiescent volcanism: examples from Vulcano and Phlegrean Fields (Italy). In: Latter, S.H. (Ed.), Volcanic Hazards. Springer, Berlin.

Martini, M., 1993. Water and fire: Vulcano island from 1977 to 1991. Geochem. J. 27, 297-303.

Martini, M., 1996. Chemical characters of the gaseous phase in different stages of volcanism: precursors and volcanic activity. In: Scarpa, P., Tilling, R.I. (Eds.), A monitoring and mitigation of volcano hazards, pp. 199-219.

Martini, M., Tonani, F., 1970. Rilevamento idrogeologico di Vulcano. Rapporti I e IA, contratto CNR no. 6900544, Palermo.

Martini, M., Giannini, L., Capaccioni, B., 1991. The influence of water on chemical changes of fumarolic gases: different characters and their implication in forecasting volcanic activity. Acta Vulcanol. 1, 13-16.

Martini, M., Piccardi, G., Cellini Legittimo, P., 1980. Geochemical surveillance of active volcanoes: data on the fumaroles of Vulcano (Aeolian Islands, Italy). Bull. Volcanol. 43 (1), 255263.

Martini, M., Piccardi, G., Cellini Legittimo, P., 1981. The effect of variations in rainfall on the chemical composition of Vulcano fumaroles. Bull. Volcanol. 44, 109-113.

Martini, M., Piccardi, G., Cellini Legittimo, P., 1986. The fumaroles of Vulcano (Italy): differences in chemical composition produced by surface environment. Geothermics 15, 205-209.

Mazor, E., Cioni, R., Corazza, E., Fratta, M., Magro, G., Matsuo, S.,
Hirabayashi, J., Shinohara, H., Martini, M., Piccardi, G., Cellini Legittimo, P., 1988. Evolution of fumarolic gases-boundary conditions set by measured parameters: case study at Vulcano, Italy. Bull. Volcanol. 50, 71-85.

Mercalli, G., Silvestri, O., 1888. Le eruzioni dell'isola di Vulcano incominciate il 3 Agosto 1888. Ann. Uff. Centr. Meteor. Geodin. X.

Minissale, A., 1992. Isotopic composition of natural thermal discharges on Vulcano island, southern Italy. J. Hydrol. 139, $15-25$.

Murowchick, J.B., Barnes, H.L., 1986. Marcasite precipitation from hydrothermal solutions. Geochim. Cosmochim. Acta 50, 26152629.

Panichi, C., Noto, P., 1992. Isotopic and chemical composition of water, steam and gas samples of the natural manifestations of the island of Vulcano (Aeolian Arc, Italy). Acta Vulcanol. 2, 297-312.

Sainte-Clare Deville, Ch., 1856. Sur les phenomenes eruptifs du Vesuve et de l'Italie Meridionale. C. R. Soc. Geol. Fr., Paris XLI, 606-610.

Shinohara, H., Matsuo, S., 1986. Results of analyses on fumarolic gases from F-1 and F-5 fumaroles of Vulcano, Italy. Geothermics 15 (2), 211-215.

Sicardi, L., 1940. Il recente ciclo dell'attività fumarolica dell'isola di Vulcano. Bull. Volcanol. 7, 85-139.

Sugisaki, R., Nagamine, K., 1995. Evolution of light hydrocarbons gases in subsurface processes: constraints from chemical equilibrium. Earth Planet. Sci. Lett. 133, 151-161.

Silvestri, O., Mercalli, G., 1891. Modo di presentarsi e cronologia delle esplosioni eruttive di Vulcano cominciate il 3-8-1888. Ann. R. Uff. Centr. Di Meteor. E Geodin. IV 10, 120-190. 